\title{
A new genus and species of gall midge (Diptera, Cecidomyiidae) associated with Myrcia retorta (Myrtaceae)
}

\author{
Valéria Cid Maia르, G. Wilson Fernandes² \& Daniel Negreiros ${ }^{2}$
}

'Departamento de Entomologia, Museu Nacional, Universidade Federal do Rio de Janeiro, Quinta da Boa Vista, São Cristóvão, 20940-040 Rio de
Janeiro-RJ, Brazil. maiavcid@acd.ufrj.br
${ }^{2}$ Ecologia Evolutiva \& Biodiversidade/DBG, ICB/Universidade Federal de Minas Gerais, Caixa Postal 486, 30161-970 Belo Horizonte-MG, Brazil.

\begin{abstract}
A new genus and species of gall midge (Diptera, Cecidomyiidae) associated with Myrcia retorta (Myrtaceae). Brethesia Maia, new genus and Brethesia myrciae Maia, new species of Cecidomyiidae are described and illustrated (male, female, pupa and gall) based on material collected in Minas Gerais (Brazil). This new species induces leaf galls on Myrcia retorta (Myrtaceae).
\end{abstract}

KEYWORDS. Asphondyliini; Brazil; Insect galls; Schizomyiina; Taxonomy.

RESUMO. Um novo gênero e espécie de mosquito galhador (Diptera, Cecidomyiidae) associados com Myrcia retorta (Myrtaceae). Brethesia myrciae, um novo gênero e espécie de Cecidomyiidae que induz galhas em Myrcia retorta (Myrtaceae) são descritos e ilustrados (macho, fêmea, pupa e galha) baseados em material coletado em Minas Gerais (Brazil).

PALAVRAS-CHAVE. Asphondyliini; Brasil; Galhas de Insetos; Schizomyiina; Taxonomia.

Myrcia retorta Cambess. (Myrtaceae) is a widely distributed tree in Brazil. It is found from the southernmost state of Rio Grande do Sul to Minas Gerais (Morais \& Lombardi 2006). Leaves are elliptical; the adaxial surface is glabrous and the abaxial is covered with thrichomes. Flowering occurs in mid-April and the fruiting season lasts from September through December.

Galling insects are readily found on $M$. retorta in several parts of Minas Gerais, including the Estação Ecológica de Pirapitinga, an ecological station of cerrado vegetation, and in the cerrados of the Parque Nacional da Serra do Cipó and Belo Horizonte. At least four galling species attack M. retorta, but the most common gall is induced by the cecidomyiid described here. The galls (Fig.1) are bright yellowish, glabrous, generally one-chambered, and can be found on both leaf surfaces. They vary from conical to tear-shaped and may be found in close aggregates. These galls are often so abundant that galled leaves may become curved and fall prematurely.

Fernandes et al. (1988) recorded three galling species on Myrcia retorta (identified as Myrcia itambensis). Four of them were identified at the family or subfamily level, one at the genus level (Dasineura sp.) and one at the species level: Myrciamyia maricaensis Maia, 1996.

We describe here a new genus and species attacking $M$. retorta. The new genus belongs to the tribe Asphondyliini owing to the number and shape of flagellomeres, the short gonostylus and female abdominal sternite 7 being at least 1.5 times length of the preceding sternite. The following characters place the genus in the subtribe Schizomyiina: legs without ventroapical spine on the first tarsomere of each leg; posterior end of the female abdominal tergite 8 generally without a bilobed structure; parameres present; and denticles of the gonostyli not fused. Schizomyiina is a cosmopolitan subtribe with 151 species in 24 genera (Gagné, 2004). Twelve genera and 48 species have been recorded for the Neotropical region (8 genera and 29 species for Brazil).

\section{MATERIALAND METHODS}

Insect galls on Myrcia retorta were sampled during several field excursions in the Estação Ecológica de Pirapitinga, Três Marias, MG during the year of 1998. Galls were collected from five different individuals of the host plant and placed into plastic bags. In the laboratory galls were placed in glass jars and left at environment temperature to await emergence of the galling adults, according to Fernandes et al. (1988). Some galls were dissected to collect immature stages of the galling insect. The gall midge specimens were prepared and mounted on slides following the method of Gagné (1994). All material, including types, are incorporated in the Diptera collection of Museu Nacional, Rio de Janeiro. Morphological terminology follows Gagné (1994). The field and laboratory work were done by G.W. Fernandes and D.Negreiros, and the taxonomy and descriptions of the new taxa were made by V.C.Maia.

\section{Brethesia Maia, gen. nov.}

Diagnosis. Female flagellomeres 9-12 progressively shortened; female circumfila reticulate; palpus one-segmented; first tarsomeres without spur; empodia much shorter than claws; claws similar on all legs; tooth of gonostylus denticulate; parameres present; aedeagus bulbous; female abdominal tergite 8 without cercilike lobes; female abdominal segment 9 short, pliable, with long setae. Pupal antennal horns short. 


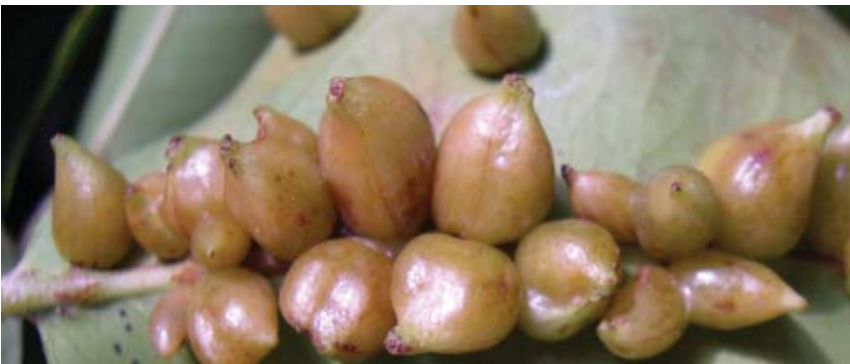

Fig. 1. Gall of Brethesia myrciae sp. nov.

Adult. Head: palpus one-segmented; male flagellomere cylindrical, without constrictions; flagellomere necks bare; female flagellomere 9-12 progressively shortened; male circumfila with complete reticulation and female with incomplete reticulation. Thorax: Wing: R5 curved, joining $\mathrm{C}$ beyond wing apex; base of M straight; Rs absent; $\mathrm{M} 3$ present; $\mathrm{CuA}$ forked; $\mathrm{CuP}$ present. First tarsomeres without spur. Abdome: aedeagus bulbous; female abdominal tergite 8 without cercilike lobes; female abdominal segment 9 short, pliable, with long setae; female cerci discrete apically.

Pupa. Head: antennal horns present; cervical seta and facial papillae absent; frons without spines. Thorax: prothoracic spiracle short. Abdominal tergites without well developed spines. Pupation in gall.

Remarks. Brethesia will key to Stephomyia Tavares, 1916 in couplet 12 of Gagné (1994). Both genera have similar circumfila, the same number of palpal segments and separate female cerci distinct at least apically, but they differ mainly in the shape of the ovipositor. Stephomyia has a short nonaciculate ovipositor (Fig. 2). The new genus has an elongate and aciculate ovipositor. While the pupae of Stephomyia have facial papillae, the pupae of Brethesia have none. The ovipositor of Brethesia resembles the ovipositor of Bruggmannia Tavares, 1906 (Fig. 3), except that the cerci are separate apically. Brethesia also differs from Bruggmannia in

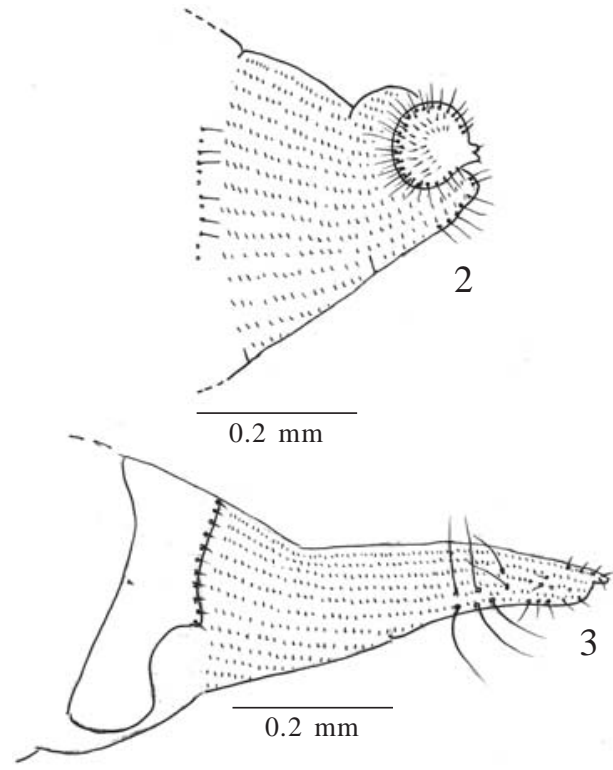

Figs. 2-3. Ovipositor. 2, Stephomyia espiralis Maia, 1994, dorsal view; 3, Bruggmannia acaudata Maia, 2005, lateral view. the number of segments of the palpus (one and three, respectively); in the shape of the flagellomeres (cylindrical in the former and constricted near middle of the nodes in the latter); the shape of circumfila (reticulate in the new genus and less appressed to the flagellomeres in Bruggmannia); dorsal spines on the second to eighth abdominal segments of the pupa (absent in the new genus and present in Bruggmannia).

Type species. Brethesia myrciae sp. nov.

Etymology. The genus is named in honour of Juan Brèthes, a French entomologist which described six genera and nine species of Neotropical gall midges between 1914 and 1922 (Gagné 1994).

\section{Brethesia myrciae Maia, sp. nov. Figs. 4-18}

Adult. Body length: $2.4-2.7 \mathrm{~mm}$ in male $(\mathrm{n}=4) ; 3.6-4.0 \mathrm{~mm}$ in female (from vertex to ovipositor completely protracted, $n=2$ ). Head (Fig. 4): eye facets circular, closely approximated. Antenna with scape obconic, pedicel globose, male circumfila with complete reticulation and female with incomplete reticulation (Figs. 5 and 6). Proportions of flagellomeres 8-12 as in Figs. 7 and 8. Flagellomeres 1 and 2 connate. Female flagellomere 12 ovoid. Frontoclypeus with 11 setae. Labrum triangular, longattenuate, with three pairs of ventral setae. Hypopharynx of same shape as labrum with long, anteriorly directed lateral setulae. Labella elongate-convex, each with long lateral setae and three mesal setae. Palpus of one cylindrical, setose segment.

Thorax: Wing (Fig. 9): length from arculus to apex: 1.75$1.80 \mathrm{~mm}$ in male $(\mathrm{n}=3) ; 2.70 \mathrm{~mm}$ in female $(\mathrm{n}=1)$. Anepimeron with vertical group of several setae. Other pleura bare. Tarsal

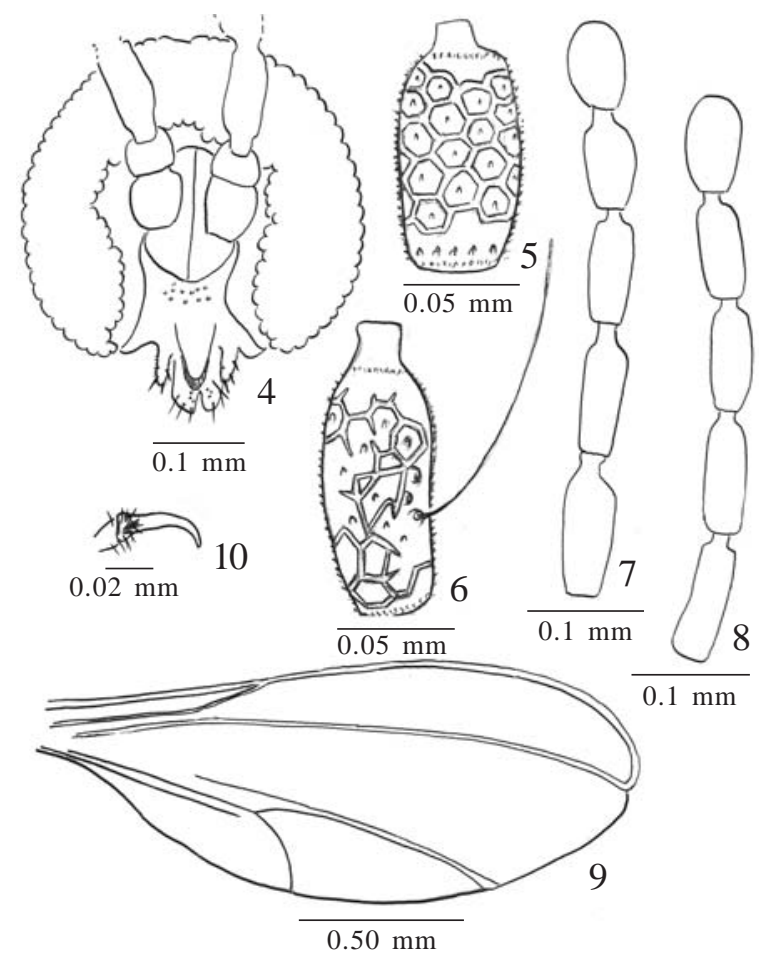

Figs. 4-10. Brethesia myrciae sp. nov. 4, Male, head, frontal view; 5, Male, flagellomere 6; 6, Female, flagellomere 5; 7, Male, flagellomeres $8-12$; 8, Female, flagellomeres 8-12; 9, Male, wing; 10, Female, midleg, tarsal claw and empodium. 


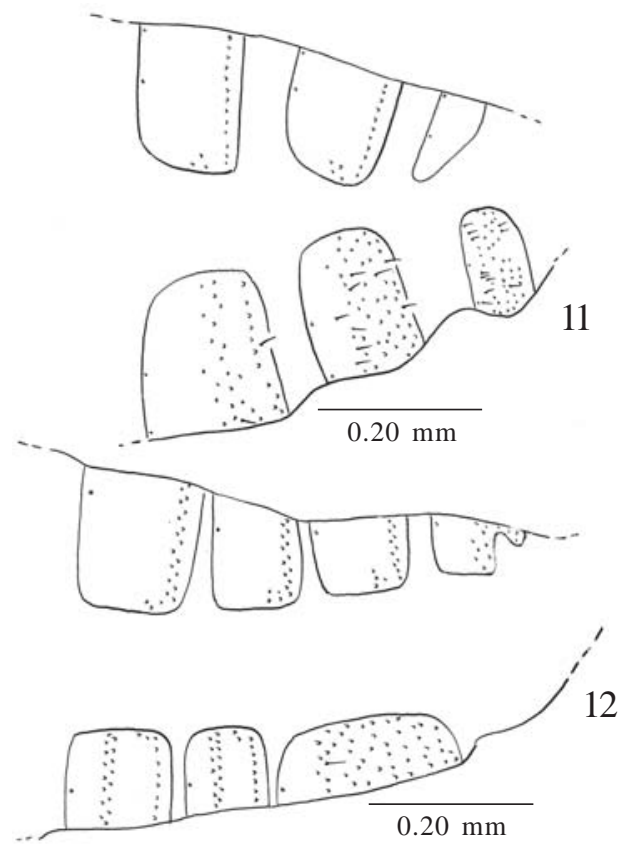

Figs. 11-12. Brethesia myrciae sp. nov. 11, Male, abdominal segments 6-8, lateral view; 12, Female, abdominal segments 6-8, lateral view.

claws curved beyond midlength, simple on all legs; pulvilli and empodia rudimentary (Fig. 10).

Male abdomen (Fig. 11): tergites 1-7 rectangular with single, complete row of caudal setae, some lateral setae, two basal trichoid sensilla and elsewhere with scattered scales. Tergite 8 with two basal trichoid sensilla, and no other setae. Sternites 2-7 rectangular and setose, setae more abundant anteriorly and mesally, and two basal trichoid sensilla. Sternite 8 rectangular and with scattered setae and two basal trichoid sensilla.

Female abdomen (Fig. 12): tergites 1-7 as in male; tergite 8 notched laterally with a group of setae on distal half and two basal trichoid sensilla; sternites 2-6 as in male. Sternite 7 with scattered setae and two basal trichoid sensilla. Sternite 8 not sclerotized.

Male terminalia (Fig. 13): gonostylus rectangular and setose, cercus reniform and setose, hypoproct deeply bilobed and setose, parameres cylindrical and setose, aedeagus bulbous. Ovipositor (Figs. 14-15) somewhat protrusible and striate, with elongate ventral setae, sparse dorsal setae and tiny, separate cerci (Fig. 16).

Pupa. Length: 2.6-3.8 mm ( $\mathrm{n}=4)$. Head (Fig. 17): antennal horn bifid, with 0.03-0.04 mm of length $(\mathrm{n}=5)$ (from antennal base to apex); cephalic setae absent; lower and lateral papillae absent; upper facial margin thickened laterally, no frontal spines. Prothoracic spiracle short, $0.07 \mathrm{~mm}$ long $(\mathrm{n}=5)$ and digitiform (Fig. 18). Abdominal tergites 2-8 covered with spinules. Terminal segment rounded.

Material examined. Holotype male, BRAZIL, Minas Gerais: Três Marias, 21.VIII.1998, D. Negreiros leg., MNRJ. Paratypes: same

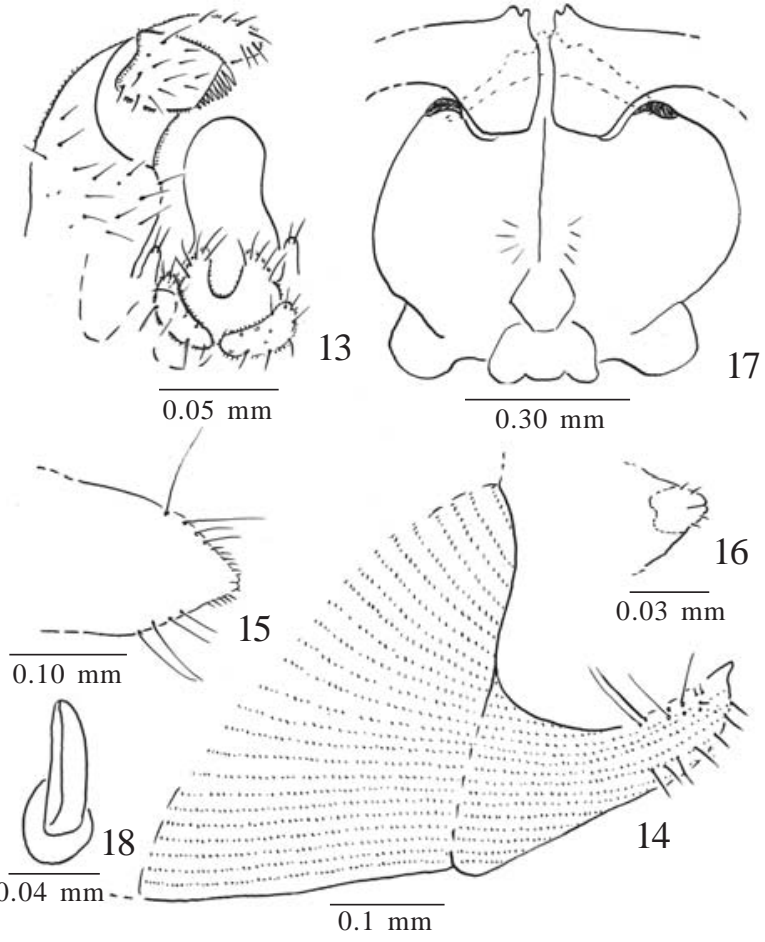

Figs. 13-18. Brethesia myrciae sp. nov. 13, Male terminalia, dorsal view; 14, Ovipositor, lateral view; 15, Ovipositor apex, dorsal view; 16, Female cerci, dorsal view; 17, Pupal head, frontal view; 18, Pupa, prothoracic spiracle.

locality, date and collector -3 males, 2 females, 6 pupal exuviae. Additional material examined: same locality, date and collector -5 males, 4 females, 8 pupal exuviae and 1 pupa.

Etymology. The specific name is the genitive of the host plant generic name.

Acknowledgements. We thank two anonymous reviewers for comments on early versions of the manuscript, the logistical support provided by Estação Ecológica de Pirapitinga-Ibama, and the grants given by CNPq (472491/2003-2, 304851/2004-3, 301197/2007-5, 472084/2007-0) and FAPERJ (E-26/171.290/2006).

\section{REFERENCES}

Fernandes, G. W.; E. T. Neto \& R. P. Martins. 1988. Ocorrência e caracterização de galhas entomógenas na vegetação do campus Pampulha da Universidade Federal de Minas Gerais. Revista Brasileira de Zoologia 5: 11-29.

Gagné, R. J. 1994. The gall midges of the Neotropical region. Ithaca, Cornell Univ. Press, $352 \mathrm{p}$.

Gagné, R. J. 2004. A catalog of the Cecidomyiidae (Diptera) of the world. Memoirs of the Entomological Society of Washington 25: 409 p.

Maia, V. C. 2001. The gall midges (Diptera, Cecidomyiidae) from three restingas of Rio de Janeiro State, Brazil. Revista Brasileira de Zoologia 18: 583-629.

Morais, P. O. \& J. A. Lombardi. 2006. A família Myrtaceae na Reserva Particular do Patrimônio Natural da Serra do Caraça, Catas Altas, Minas Gerais, Brasil. Lundiana 7: 3-32.

Tavares, J. S. 1916. Cecidomyias novas do Brazil. Brotéria, Série Zoológica 14: 36-57.

Received 08/05/2008; accepted 25/09/2008 